\title{
Peran kecambah kacang hijau (Phaseolus radiatus (L.)) pada sel lemak retroperitoneal tikus Sprague Dawley yang diberi diet tinggi lemak
}

The role of mung bean sprouts (Phaseolus radiatus (L.)) on retroperitoneal fat cells of Sprague Dawley rats fed high-fat diet

\author{
Dwi Lestari ${ }^{1}$, Wiryatun Lestariana ${ }^{2}$, Lily Arsanti Lestari ${ }^{3}$, Arta Farmawati ${ }^{2}$ \\ ${ }^{1}$ Program Studi S1 Gizi, Fakultas Kesehatan Universitas Nahdlatul Ulama Nusa Tenggara Barat \\ ${ }^{2}$ Departemen Biokimia, Fakultas Kedokteran, Kesehatan Masyarakat, dan Keperawatan Universitas Gadjah Mada \\ ${ }^{3}$ Departemen Gizi Kesehatan, Fakultas Kedokteran, Kesehatan Masyarakat, dan Keperawatan Universitas Gadjah Mada
}

\begin{abstract}
Background: The tendency of current lifestyles with high consumption patterns of fat is one of the factors causing obesity which is a risk of cardiovascular disease. Prevention of cardiovascular disease can be done by adopting dietary pattern that is rich in antioxidants including consumption of sources of vitamin E. Sprouts from mung beans contain vitamin E and phytochemicals rich in antioxidants, so they can be used as an alternative to prevent hyperlipidemia sourced from daily functional food. Objective: To assess the effects of mung bean sprouts on retroperitoneal fat weight, cell number and cell diameter in rats fed high fat feed. Methods: This research is an experimental study with post-test design with control group. Thirty four male Sprague Dawley rats \pm 2 months old were divided into five groups, group I (standard feed), group II (high-fat feed), group III (high-fat feed and intervention of feeding tube of mung bean sprout $0.67 \mathrm{~g} / 200 \mathrm{~g} \mathrm{BW}$ ), group IV (high fat feed and intervention of feeding tube of mung bean sprout $1.34 \mathrm{~g} / 200 \mathrm{~g} \mathrm{BW}$ ), and group V (highfat feed and $23 \mathrm{IU}$ dose of vitamin E supplement with feeding tube). After adaptation for three days, the intervention was carried out for four weeks. Analysis of fat weight, fat cell number and fat cell diameter was done after the treatments. Data analysis using One-Way ANOVA test. Results: Mung bean sprout dose of $1.34 \mathrm{~g}$ given for 4 weeks did not significantly decrease fat weight and cell number, but it decreased the diameter of retroperitoneal fat cells. Conclusions: Mung bean sprouts dose $1.34 \mathrm{~g}$ was better than dose of $0.67 \mathrm{~g}$ and vitamin $E$ supplementation in reducing the diameter of retroperitoneal fat cells in rats fed a high-fat diet.
\end{abstract}

KEYWORDS: high-fat diet; mung bean sprouts; retroperitoneal fat cells

\begin{abstract}
ABSTRAK
Latar belakang: Kecenderungan gaya hidup saat ini dengan pola konsumsi lemak yang tinggi merupakan salah satu faktor penyebab obesitas yang merupakan risiko penyakit kardiovaskular. Pencegahan penyakit kardiovaskular dapat dilakukan dengan pengaturan pola makan yang kaya antioksidan termasuk konsumsi sumber vitamin E. Kecambah dari kacang hijau mengandung vitamin E dan phytochemical kaya antioksidan sehingga dapat digunakan sebagai alternatif untuk mencegah hiperlipidemia. Tujuan: Penelitian ini bertujuan mengetahui pengaruh pemberian kecambah kacang hijau terhadap berat lemak retroperitoneal, jumlah sel, dan diameter sel pada tikus yang diberi pakan tinggi lemak. Metode: Jenis penelitian eksperimental dengan desain post test dan kelompok kontrol. Sebanyak 34 tikus Sprague Dawley jantan berusia \pm 2 bulan dibagi menjadi 5 kelompok yaitu kelompok I (pakan standar), kelompok II (pakan tinggi lemak), kelompok III (pakan tinggi lemak dan sonde kecambah kacang hijau 0,67 g/200 g BB), kelompok IV (pakan tinggi lemak dan sonde kecambah kacang hijau 1,34 g/200 g BB), dan kelompok V (pakan tinggi lemak dan suplemen vitamin E dosis 23 IU secara sonde). Setelah adaptasi selama 3 hari, dilakukan intervensi selama 4 minggu. Analisis berat lemak, jumlah sel lemak dan diameter sel lemak dilakukan sesudah perlakuan. Analisis data menggunakan uji One Way ANOVA. Hasil: Kecambah kacang hijau dosis 1,34 g selama 4 minggu tidak berpengaruh signifikan terhadap penurunan berat lemak dan jumlah sel, tetapi dapat menurunkan diameter sel lemak retroperitoneal. Simpulan: Pemberian kecambah kacang hijau dosis 1,34 g lebih baik daripada dosis 0,67 $\mathrm{g}$ dan suplementasi vitamin $\mathrm{E}$ dalam menurunkan diameter sel lemak retroperitoneal tikus yang diberi diet tinggi lemak.
\end{abstract}

KATA KUNCI: diet tinggi lemak; kecambah kacang hijau; sel lemak retroperitoneal

Korespondensi: Dwi Lestari, Universitas Nahdlatul Ulama Nusa Tenggara Barat, Jl. Pendidikan No. 06 Kota Mataram, Provinsi Nusa Tenggara Barat, e-mail: dwijauza@ rocketmail.com

Cara sitasi: Lestari D, Lestariana W, Lestari LA, Farmawati A. Peran kecambah kacang hijau (Phaseolus radiatus (L.)) pada sel lemak retroperitoneal tikus Sprague Dawley yang diberi diet tinggi lemak. Jurnal Gizi Klinik Indonesia. 2019;16(1):31-39. doi: 10.22146/ijcn.41676 


\section{PENDAHULUAN}

Penyakit degeneratif merupakan penyakit yang terkait pola perilaku yaitu pola makan, gaya hidup serta aktivitas fisik. Kejadian ini muncul akibat kecenderungan masyarakat yang sering mengkonsumsi makanan yang tidak seimbang, tinggi lemak dan energi tetapi rendah serat, vitamin, dan mineral serta gaya hidup yang kurang gerak (sedentary lifestyles). Pada tahun 2015, diperkirakan sebanyak 2,3 milliar penduduk dunia mengalami overweight dan sekitar 700 juta akan mengalami obesitas (1). Obesitas merupakan faktor risiko penyakit degeneratif seperti dislipidemia, hipertensi, diabetes mellitus (DM) tipe 2, penyakit jantung koroner, gagal jantung, stroke, kanker, dan osteoarthritis $(2,3)$.

Prevalensi obesitas mengalami peningkatan setiap tahun, yaitu di Amerika Serikat terjadi peningkatan obesitas dari $13 \%$ pada tahun 1960 -an menjadi $32 \%$ pada tahun 2004 (4). Berdasarkan data riset kesehatan dasar (Riskesdas) tahun 2013, prevalensi nasional obesitas sentral berdasarkan indikator lingkar perut (LP) sebesar $26,6 \%$ yang meningkat dibandingkan prevalensi pada tahun 2007 (18,8\%). Obesitas sentral merupakan faktor risiko yang berkaitan erat dengan kejadian penyakit kronis, seperti penyakit jantung dan DM tipe $2(5,6)$.

Penelitian terkait antioksidan banyak dilakukan untuk mengetahui peran antioksidan dalam mencegah pembentukan radikal bebas. Antioksidan terbukti sangat berpengaruh terhadap perubahan ukuran sel lemak (7). Reduksi lemak tubuh dapat mengurangi risiko terjadinya penyakit kronis serta menurunkan angka morbiditas dan mortalitas (8). Salah satu sumber antioksidan yang sering dikonsumsi masyarakat yaitu kecambah kacang hijau (tauge). Kandungan zat gizi yang terdapat pada kecambah kacang hijau diantaranya vitamin $C, \beta$-caroten, vitamin $\mathrm{E}$ ( $\alpha$-tokoferol), fenol, falvonoid, fitosterol yang berperan sebagai antioksidan, dan beberapa mineral seperti kalsium, magnesium, zinc, selenium, mangan, tembaga, dan besi yang merupakan komponen antioksidan endogen (9-11).

Penelitian terdahulu menunjukkan antioksidan yang terkandung dalam kecambah kacang hijau diperkirakan dapat mengurangi kerusakan sel akibat pemberian diet tinggi lemak. Studi sebelumnya (12) menemukan bahwa pemberian ekstrak tauge dapat menurunkan ketebalan tunika intima-media aorta yang dipapar hiperkolesterolemia. Selain itu, penelitian lain $(13,14)$ juga menunjukkan bahwa pemberian ekstrak tauge secara signifikan mampu mengurangi kerusakan ginjal akibat pemberian obat paracetamol dosis toksik. Obesitas terkait dengan kejadian dislipidemia yaitu adanya peningkatan low-density lipoprotein (LDL) dalam sirkulasi oleh karena asupan makanan tinggi lemak mengakibatkan hati tidak dapat menuptake seluruhnya. Oleh karena itu, LDL mengalami oksidasi dan bersifat toksik terhadap endotel pembuluh darah. Di samping itu, LDL teroksidasi juga memicu terbentuknya radikal bebas. Disfungsi endotel merupakan lesi awal pembentukan ateroma pada aterosklerosis. Pada aterosklerosis terjadi peradangan pembuluh darah arteri yang ditandai dengan deposit kolagen, kolesterol, lemak, proliferasi miosit, makrofag, leukosit, dan debris seluler yang mengakibatkan penebalan dan pengerasan dinding arteri (15).

Studi yang meneliti pengaruh kecambah kacang hijau terhadap sel lemak retroperitoneal tikus sejauh ini belum pernah dilakukan. Studi yang melihat parameter sel lemak retroperitoneal merupakan penelitian yang unik dan baru karena dapat melihat risiko obesitas sentral yang berkaitan erat dengan kejadian penyakit kardiovaskuler. Dengan demikian, penelitian ini perlu dilakukan yang bertujuan untuk mengetahui peranan pemberian kecambah kacang hijau terhadap berat lemak, jumlah, dan ukuran sel lemak retroperitoneal tikus Sprague Dawley yang diberi diet tinggi lemak.

\section{BADAN DAN METODE}

\section{Desain dan sampel}

Penelitian ini merupakan penelitian eksperimental dengan rancangan post-test only control group design yang dilaksanakan pada bulan Mei - Juni 2015. Pada rancangan ini tikus dibagi menjadi 5 kelompok secara random. Penelitian dilakukan di Laboratorium Pangan dan Gizi Pusat Antar Universitas (PAU) Universitas Gadjah Mada dan Laboratorium Patologi Anatomi di Fakultas Kedokteran Hewan Universitas Gadjah Mada. Populasi yang digunakan dalam penelitian ini adalah tikus putih galur Sprague Dawley yang diperoleh dari 
bagian produksi ternak daging kerja dan aneka ternak Departemen Ilmu Produksi dan Teknologi Peternakan Fakultas Peternakan Institut Pertanian Bogor dengan kriteria yaitu berjenis kelamin jantan, sehat yang dibuktikan dengan pemeriksaan hemoglobin $(\mathrm{Hb})$, dan berumur \pm 2 bulan dengan berat badan 147-222 g.

Besar sampel dalam penelitian ini ditentukan berdasarkan rumus Federer sehingga besar sampel minimal adalah 5 ekor. Penentuan tikus untuk setiap kelompok dilakukan dengan simple random sampling. Tikus pada penelitian ini dibagi menjadi lima kelompok, yaitu kelompok kontrol normal $(\mathrm{KN})(\mathrm{n}=7)$; kelompok kontrol diet tinggi lemak (KP) $(n=7)$; kelompok diet tinggi lemak dan intervensi 0,67 g kecambah kacang hijau (P1) $(\mathrm{n}=7)$; kelompok diet tinggi lemak dan intervensi 1,34 g kecambah kacang hijau (P2) (n=7); dan kelompok diet tinggi lemak dan intervensi suplementasi vitamin E (P3) (n=6). Pada kelompok kontrol diberikan pakan diet standar sedangkan kelompok kedua dan kelompok perlakuan diberikan pakan diet tinggi lemak.

\section{Pengumpulan dan pengukuran data}

Pada akhir penelitian, dilakukan penimbangan tikus sebelum dikorbankan dan dibedah untuk diambil jaringan lemak retroperitoneal. Proses pembedahan dan pengambilan jaringan lemak untuk penimbangan dilakukan oleh orang yang sama. Jaringan lemak tersebut kemudian ditimbang untuk selanjutnya dilakukan pembuatan sediaan histologis untuk mengetahui jumlah sel dan diameter sel lemak retroperitoneal yang dilakukan di Laboratorium Patologi Anatomi di Fakultas Kedokteran Hewan Universitas Gadjah Mada.

Penghitungan berat lemak dilakukan dengan penimbangan jaringan lemak yang terdapat di dalam ruangan antara fascia pelapis dinding interna abdomen dan peritoneum dengan menggunakan timbangan digital. Penghitungan jumlah sel dan pengukuran diameter sel lemak retroperitoneal tikus dilakukan dalam 10 lapang pandang per preparat menggunakan perbesaran 400x (perbesaran objektif mikroskop cahaya 40x, perbesaran okuler fungsi Image Raster software Optilab 10x). Setiap lapang pandang dihitung jumlah sel lemak yang tampak utuh (batas sel tegas), kemudian dilakukan pengukuran diameter dengan cara menarik garis lurus terpanjang pada sel lemak dan dinyatakan dalam $\mu \mathrm{m}$. Setelah itu, melakukan penghitungan total jumlah sel lemak dan diukur rerata diameter sel lemak pada 10 lapang pandang.

\section{Analisis data}

Analisis data menggunakan uji parametrik yaitu Analisis of Variance (ANOVA) One-Way test untuk mengetahui perbedaan antarkelompok perlakuan. Data tersebut dinyatakan berbeda signifikan secara statistik apabila nilai $\mathrm{p}<0,05$. Penelitian ini telah mendapatkan surat kelaikan etik (ethics approval) dengan nomor KE/FK/485/EC dari Komisi Etik Penelitian Fakultas Kedokteran Universitas Gadjah Mada tanggal 8 Mei 2015.

\section{HASIL}

\section{Berat badan dan kadar hemoglobin}

Karakteristik sampel pada penelitian ini meliputi jenis tikus, usia, berat badan, dan kadar Hb. Seluruh tikus berjenis kelamin jantan dan berusia \pm 8 minggu dengan berat badan tikus pada awal penelitian sebesar 147-222 g. Tabel 1 menunjukkan bahwa berat badan awal dan kadar $\mathrm{Hb}$ tidak berbeda signifikan antarkelompok $(\mathrm{p}>0,05)$. Hal ini menunjukkan bahwa semua kelompok

Tabel 1. Berat badan dan kadar hemoglobin sebelum perlakuan

\begin{tabular}{lccc}
\hline Parameter & Kelompok & Rerata \pm SD & p* $^{*}$ \\
\hline Berat badan $(\mathrm{g})$ & KN $(\mathrm{n}=7)$ & $182,42 \pm 20,5$ & 0,341 \\
& KP $(\mathrm{n}=7)$ & $179,28 \pm 16,34$ & \\
& P1 $(\mathrm{n}=7)$ & $175,71 \pm 16,25$ & \\
& P2 (n=7) & $180,57 \pm 9,71$ & \\
& P3 (n=6) & $165,16 \pm 14,03$ & \\
\hline Hemoglobin (g/dL) & KN (n=7) & $10,91 \pm 0,209$ & 0,456 \\
& KP (n=7) & $11,01 \pm 0,237$ & \\
& P1 (n=7) & $11,13 \pm 0,275$ & \\
& P2 (n=7) & $11,07 \pm 0,201$ & \\
& P3 (n=6) & $11,00 \pm 0,227$ & \\
\hline
\end{tabular}

*Uji statistik menggunakan ANOVA one-way test $(\mathrm{p}<0,05)$;

$\mathrm{KN}=$ Kelompok tikus kontrol negatif

$\mathrm{KP}=$ Kelompok tikus yang diberi diet tinggi lemak (kontrol positif)

$\mathrm{P} 1=$ Kelompok tikus yang diberi diet tinggi lemak + kecambah kacang hijau dosis $0,67 \mathrm{~g}$

P2 = Kelompok tikus yang diberi diet tinggi lemak + kecambah kacang hijau dosis $1,34 \mathrm{~g}$

P3 $=$ Kelompok tikus yang diberi diet tinggi lemak + suplementasi vitamin E 23 IU 
Tabel 2. Berat lemak, jumlah sel, dan diameter sel lemak retroperitoneal tikus

\begin{tabular}{lccc}
\hline \multirow{2}{*}{ Kelompok } & \multicolumn{3}{c}{ Lemak retroperitoneal $($ rerata \pm SD) } \\
\cline { 2 - 4 } & Berat $(\mathbf{g})$ & Jumlah & Diameter $(\boldsymbol{\mu m})$ \\
\hline KN (n=7) & $2,78 \pm 0,63$ & $17,71 \pm 2,36$ & $65,04 \pm 5,27^{\mathrm{a} * *}$ \\
KP $(\mathrm{n}=7)$ & $3,19 \pm 0,52$ & $17,85 \pm 3,23$ & $68,55 \pm 4,31^{\mathrm{ab}}$ \\
P1 (n=7) & $3,56 \pm 1,24$ & $15,71 \pm 3,90$ & $73,13 \pm 8,62^{\mathrm{ab}}$ \\
P2 (n=7) & $3,52 \pm 0,88$ & $15,28 \pm 2,56$ & $69,33 \pm 6,44^{\mathrm{ab}}$ \\
P3 (n=6) & $3,72 \pm 0,78$ & $15,33 \pm 3,14$ & $75,63 \pm 5,30^{\mathrm{b}}$ \\
Sig. p)* & 0,295 & 0,332 & $0,038^{*}$
\end{tabular}

*Uji statistik menggunakan ANOVA one way test $(\mathrm{p}<0,05)$

$* *$ Notasi yang berbeda menunjukkan perbedaan signifikan $(\mathrm{p}<0,05)$

tikus memiliki kondisi kesehatan yang sama sebelum diberikan perlakuan. Pengukuran kadar $\mathrm{Hb}$ bertujuan untuk mengetahui adanya anemia dengan kisaran batas normal pada tikus putih antara $11,1-18 \mathrm{~g} / \mathrm{dl}(16,17)$. Penelitian ini menunjukkan bahwa kadar $\mathrm{Hb}$ yang terukur antara 10,91 - 11,13 g/dl yaitu masih dalam batas normal.

\section{Berat sel lemak retroperitoneal}

Sebelum dilakukan pembuatan preparat histologis, lemak retroperitoneal tikus dilakukan penimbangan terlebih dahulu. Kelompok P3 memiliki berat lemak retroperitoneal tertinggi yaitu sebesar 3,72 $\pm 0,78 \mathrm{~g}$ dibandingkan dengan kelompok KN sebesar 2,78 $\pm 0,63$ g. Hasil uji statistik antar kelompok menunjukkan bahwa tidak ada perbedaan yang bermakna berat lemak retroperitoneal akhir antar kelompok $(\mathrm{p}=0,295)$ (Tabel 2).

\section{Jumlah sel lemak retroperitoneal}

Berdasarkan hasil penghitungan sel lemak diketahui bahwa kelompok P2 memiliki jumlah sel lemak retroperitoneal yang paling sedikit $(15,28 \pm 2,56)$ dibandingkan dengan kelompok P3 $(15,33 \pm 3,14), \mathrm{P} 1$ $(15,71 \pm 3,14)$, KN $(17,71 \pm 2,36)$, dan KP $(17,85 \pm 3,23)$. Hal ini menunjukkan bahwa pemberian kecambah kacang hijau dan suplementasi vitamin E menghasilkan jumlah sel lemak retroperitoneal yang lebih sedikit daripada kelompok KP pada tikus yang diberi diet tinggi lemak. Namun, berdasarkan hasil analisis statistik ANOVA one-way test menunjukkan bahwa hasil tersebut tidak signifikan antara kelima kelompok perlakuan dengan nilai $\mathrm{p}=0,332$.

\section{Diameter sel lemak retroperitoneal}

Hasil pengukuran menunjukkan bahwa kelompok P3 memiliki diameter sel lemak retroperitoneal terbesar $(75,63 \pm 5,30 \mu \mathrm{m})$ dibandingkan dengan kelompok P1 $(73,13 \pm 8,62 \mu \mathrm{m})$, kelompok P2 $(69,33 \pm 6,44 \mu \mathrm{m}), \mathrm{KP}$ $(68,55 \pm 4,31 \mu \mathrm{m})$ dan $\mathrm{KN}(65,04 \pm 5,27 \mu \mathrm{m})$. Dengan demikian, dapat disimpulkan bahwa pemberian kecambah kacang hijau dosis 1,34 g (P2) akan menghasilkan sel lemak retroperitoneal dengan diameter yang lebih kecil daripada pemberian kecambah kacang hijau dosis 0,67 $\mathrm{g}$ (P1) dan vitamin E (P3) pada tikus yang diberi diet tinggi lemak. Analisis statistik menggunakan ANOVA one-way test menunjukkan hasil yang signifikan antara kelima kelompok perlakuan dengan nilai $\mathrm{p}=0,038$.

\section{BAHASAN}

\section{Berat badan dan kadar hemoglobin}

Pada awal penelitian, semua kelompok tikus memiliki berat yang sama sebelum diberikan perlakuan. Salah satu indikator status kesehatan tikus selain asupan pakan dan berat badan, yaitu melalui kadar $\mathrm{Hb}$ yang diperiksa pada saat sebelum intervensi dan akhir intervensi sebelum pembedahan. Berdasarkan hasil uji statistik menunjukkan bahwa tidak ada perbedaan signifikan kadar $\mathrm{Hb}$ antar kelompok tikus perlakuan $(p=0,456)$. Hal ini menunjukkan bahwa kondisi sampel homogen untuk semua kelompok.

\section{Berat lemak retroperitoneal}

Hasil penelitian menunjukkan bahwa pemberian suplementasi vitamin E (P3) selama 4 minggu menghasilkan berat lemak retroperitoneal yang lebih banyak $(3,72 \pm 0,78 \mathrm{~g})$ dibandingkan dengan pemberian kecambah kacang hijau dosis $0,67 \mathrm{~g}(3,56 \pm 1,24 \mathrm{~g})$ dan dosis $1,34 \mathrm{~g}(3,52 \pm 0,88 \mathrm{~g})$ serta pada kelompok kontrol positif $(3,19 \pm 0,52 \mathrm{~g})$ dan kelompok kontrol negatif $(2,78 \pm 0,63 \mathrm{~g})$. Hasil ini didukung dengan data persentase kenaikan berat badan di akhir penelitian yang tertinggi pada kelompok P3 (50,55\%), diikuti kelompok P1 (48,29\%), P2 (46,12\%), KP (39,36\%) dan KN (33,75\%). Hal ini menunjukkan bahwa semakin tinggi pemberian dosis kecambah kacang hijau, maka akan menghasilkan 
berat lemak yang lebih rendah. Meskipun berdasarkan hasil uji analisis statistik tidak terdapat perbedaan yang signifikan antarkelompok perlakuan.

Kelompok kontrol positif (KP) memiliki berat lemak yang lebih rendah dibandingkan dengan kelompok perlakuan karena tikus pada kelompok KP ini memiliki asupan pakan rendah yang ditandai dengan berat badan akhir yang lebih rendah dibandingkan dengan kelompok perlakuan. Berat badan yang rendah tersebut yang menyebabkan kelompok KP memiliki berat lemak yang lebih rendah dibandingkan dengan kelompok perlakuan. Hal ini menunjukkan bahwa pemberian kecambah kacang hijau mampu meningkatkan asupan pakan yang dibuktikan dengan data asupan pakan pada kelompok perlakuan kecambah kacang hijau lebih tinggi dibandingkan dengan kelompok KP. Hal ini karena kandungan vitamin B1 (thiamin) yang terdapat dalam kecambah kacang hijau mampu meningkatkan nafsu makan. Selain itu, thiamin juga merupakan bagian dari koenzim yang berperan penting dalam oksidasi karbohidrat $(18,19)$.

Kelompok perlakuan kecambah kacang hijau memiliki berat lemak yang lebih tinggi jika dibandingkan dengan kelompok KP. Hal ini didukung dengan data asupan pakan pada kelompok kecambah kacang hijau yang lebih tinggi jika dibandingkan dengan kelompok KP. Pemberian diet tinggi lemak dapat memicu terjadinya stres oksidatif yang merupakan akibat oksidasi dari asam lemak bebas dan LDL. Keadaan ini juga dipengaruhi oleh spesies oksigen reaktif (ROS) yang merupakan molekul oksidan relatif tinggi dan memiliki sifat sangat tidak stabil sehingga cepat bereaksi dengan molekul lain. Selain itu, pemberian pakan dengan diet tinggi lemak dapat memicu terjadinya lipogenesis yang berpengaruh terhadap sel lemak retroperitoneal $(20,21)$.

Selain itu, hasil penelitian ini menunjukkan bahwa semakin tinggi dosis kecambah kacang hijau yang diberikan maka terjadi penurunan berat lemak. Hal ini mungkin terkait dengan kandungan kecambah kacang hijau berupa tokotrienol dan tokoferol yang memiliki efek penghambatan terhadap 3-hidroksi-3metilglutaril koenzim A (HMG-KoA reduktase) sehingga menurunkan sintesis kolesterol. Selain itu, kecambah kacang hijau juga memiliki efek antilipogenik yakni mampu menurunkan laju lipogenesis pada studi yang dilakukan pada hewan coba. Penurunan laju lipogenesis tersebut melalui penghambatan enzim lipoprotein lipase (LPL) sehingga hasil pemecahan trigliserida menjadi asam lemak bebas akan ditekan yang menyebabkan asam lemak bebas di aliran darah berkurang dan penyimpanan di jaringan adiposa juga akan berkurang $(22,23)$.

Penjelasan terkait dengan berat lemak retroperitoneal yang tertinggi pada hasil penelitian ini, yaitu karena suplementasi vitamin E hanya murni memiliki satu jenis antioksidan berupa $\alpha$-tokoferol sedangkan kecambah kacang hijau memiliki berbagai antioksidan seperti vitamin E ( $\alpha$-tokoferol), vitamin C, fitosterol, flavonoid, fenol, selenium, mangan, tembaga, zinc, dan besi yang mampu menghambat terjadinya lipogenesis $(10,24)$. Selain itu, kandungan serat yang terdapat di dalam kecambah kacang hijau diketahui mampu mengikat kolesterol dalam usus, menghambat absorbsi epitel usus, meningkatkan peristaltik serta mempercepat keluarnya kolesterol bersama feses sehingga dapat menghambat jumlah kadar trigliserida yang berperan mencegah terjadinya lipogenesis (25).

Peningkatan berat lemak yang terjadi pada tikus yang diberi suplementasi vitamin E karena terdapat penambahan minyak kedelai murni sebanyak $0,4 \mathrm{~mL}$ $(0,36 \mathrm{~g}$ lemak). Penambahan minyak kedelai ini bertujuan sebagai media pemberian suplementasi vitamin E karena jika diberikan secara oral tidak memungkinkan sehingga digunakan minyak kedelai untuk melarutkan vitamin $\mathrm{E}$ tersebut. Alasan penggunaan minyak karena vitamin $\mathrm{E}$ merupakan vitamin yang larut di dalam lemak. Pemberian minyak kedelai ini menyebabkan berat lemak pada tikus kelompok P3 meningkat karena minyak yang diberikan tersebut sangat mudah diserap tubuh sehingga lebih mudah terjadinya lipogenesis (24).

\section{Jumlah sel lemak retroperitoneal}

Hasil penelitian menunjukkan bahwa pemberian kecambah kacang hijau dengan dosis 1,34 g selama 4 minggu akan menghasilkan jumlah sel lemak retroperitoneal yang lebih sedikit $(15,28 \pm 2,56)$ dibandingkan dengan pemberian kecambah kacang hijau dosis $0,67 \mathrm{~g}(15,71 \pm 3,90)$, suplementasi vitamin E $(15,33 \pm 3,14)$, kelompok KN $(17,71 \pm 2,36)$, dan 
kelompok KP $(17,85 \pm 3,23)$. Pemberian diet tinggi lemak pada kelompok KP akan menghasilkan jumlah sel lemak yang lebih banyak dibandingkan dengan kelompok yang diberikan kecambah kacang hijau dan suplementasi vitamin E. Hal ini terjadi karena umur tikus yang digunakan dalam penelitian ini masih dalam tahap berkembang dan lamanya intervensi juga ikut mempengaruhi. Pemberian diet tinggi lemak dapat meningkatkan jumlah sel lemak pada tikus yang berusia 24 sampai 105 hari (26). Pendapat ini didukung oleh pernyataan bahwa jumlah sel lemak akan meningkat secara lambat ketika tikus berusia lebih dari 12-14 minggu dan lebih cenderung untuk mengalami peningkatan ukuran sel lemak (27). Hal ini menunjukkan bahwa pemberian diet tinggi lemak di tahap awal akan mampu meningkatkan jumlah sel adiposit kemudian ketika telah berlangsung lama maka akan cenderung terjadi pembesaran ukuran diameter sel adiposit karena adanya penumpukan lemak yang terkait dengan risiko gangguan metabolik (28-30). Penelitian ini merupakan penelitian yang berbasis preventif sehingga pemberian perlakuan kecambah kacang hijau diharapkan mampu mengurangi jumlah sel lemak yang terbentuk akibat diet tinggi lemak.

Lebih lanjut, studi ini menunjukkan bahwa kecambah kacang hijau memiliki tingkat efektivitas yang sama dengan suplementasi vitamin E dalam mencegah peningkatan jumlah sel akibat diet tinggi lemak. Hal ini terbukti secara praktis yaitu pemberian kecambah kacang hijau dan suplementasi vitamin E lebih baik dibandingkan dengan kelompok KP. Kandungan vitamin E ( $\alpha$-tokoferol) pada kecambah kacang dan suplementasi vitamin $\mathrm{E}$ dengan dosis 23 IU yang berperan pada penghambatan proses adipogenesis. Studi sebelumnya melaporakan bahwa vitamin $\mathrm{E}$ dapat menghambat proses adipogenesis serta mampu meningkatkan ekspresi gen $P P A R-\gamma 2$, yang merupakan salah satu faktor transkripsi utama pada proses adipogenesis yaitu PPAR- $\gamma$. Vitamin E dalam kecambah kacang hijau dan suplementasi vitamin E tersebut dapat menghambat diferensiasi preadiposit 3T3-L1 yang menyebabkan berkurangnya jumlah adiposit dewasa yang terbentuk (21).

Jumlah sel lemak pada kelompok tikus dengan pemberian kecambah kacang hijau dosis 1,34 g tampak lebih sedikit $(15,28 \pm 2,56)$ dibandingkan pada kelompok tikus dengan suplementasi vitamin E $(15,33 \pm 3,14)$. Hal ini disebabkan oleh aktivitas anti-aterogenik pada kecambah kacang hijau yang berdasarkan pada efek stimulan yang terjadi, yaitu baik secara oksidatif maupun non-oksidatif. Pada mekanisme oksidatif, kecambah kacang hijau berperan untuk mencegah aterogenik dengan memproteksi biomolekul seluler penting seperti lipid dan lipoprotein. Sementara pada mekanisme non-oksidatif, efek antiaterogenik kecambah kacang hijau bekerja sebagai agen hipokolesterolemik dengan menghambat laju 3-hydroxy-3-methylglutaryl-coenzim A (HMG-CoA) reduktase yang berperan penting pada sintesis kolesterol dan mengaktifkan reseptor LDL (23). Status antioksidan ini berpengaruh terhadap perbaikan profil lipid dan pencegahan oksidasi LDL kolesterol sehingga dapat mencegah pembentukan lipogenesis.

Selain itu, kandungan zat gizi dan antioksidan lain dalam kecambah kacang hijau yang ikut berperan dalam menghambat proses adipogenesis yaitu vitamin C, fitosterol, flavonoid, fenol, selenium, mangan, tembaga, zinc, dan besi serta kandungan serat yang mampu menghambat terjadinya lipogenesis $(10,24,25)$. Hal ini sejalan dengan penelitian sebelumnya (31) yang menyatakan bahwa individu dengan diet yang banyak mengandung senyawa antioksidan, vitamin $\mathrm{C}$, dan vitamin $\mathrm{E}$ memiliki risiko terkena penyakit akibat spesies oksigen reaktif lebih rendah dibandingkan dengan individu dengan diet yang kurang senyawa antioksidan.

\section{Diameter sel lemak retroperitoneal}

Penelitian ini menunjukkan bahwa pemberian suplementasi vitamin $\mathrm{E}$ akan menghasilkan diameter sel lemak yang paling besar $(75,63 \pm 5,30 \mu \mathrm{m})$ dibandingkan dengan pemberian kecambah kacang hijau pada dosis $0,67 \mathrm{~g}(73,13 \pm 8,62 \mu \mathrm{m})$ maupun dosis $1,34 \mathrm{~g}(69,33 \pm 6,44$ $\mu \mathrm{m})$ serta $\mathrm{KP}(68,55 \pm 4,31 \mu \mathrm{m})$ dan $\mathrm{KN}(65,04 \pm 5,27 \mu \mathrm{m})$. Hasil ini didukung dengan data persentase kenaikan berat badan (50,55\%) dan berat lemak yang tertinggi $(3,72 \pm 0,78 \mathrm{~g})$ pada kelompok pemberian suplementasi vitamin E jika dibandingkan dengan kelompok perlakuan lainnya. Dengan demikian, pengaruh kecambah kacang hijau terhadap lipogenesis dan metabolisme lemak tergantung pada dosis. Diameter sel lemak yang terbesar pada kelompok tikus suplementasi vitamin $\mathrm{E}$ 
kemungkinan karena kandungan suplementasi vitamin E hanya murni mengandung satu jenis antioksidan yaitu vitamin E dalam bentuk $\alpha$-tokoferol sedangkan pada kecambah kacang hijau memiliki banyak kandungan antioksidan seperti vitamin E, vitamin C, zat fenol, flavonoid serta kandungan serat yang berfungsi untuk menekan biosintensis kolesterol dan lipogenesis $(10,24)$.

Penambahan sebesar $0,4 \mathrm{~mL}$ minyak kedelai murni atau sebesar 0,36 g lemak juga mempengaruhi diameter sel lemak pada kelompok tikus yang diberi suplementasi vitamin E karena minyak memiliki sifat mudah diserap sehingga mudah terjadi lipogenesis. Hal ini didukung dengan data berat lemak pada kelompok P3 yang tertinggi, yaitu sebesar 3,72 $\pm 0,78 \mathrm{~g}$ dibandingkan pada kelompok P1 (dosis kecambah 0,67 g) dan P2 (dosis kecambah 1,34 g). Berdasarkan hasil uji analisis untuk kelima kelompok perlakuan menunjukkan perbedaan yang signifikan. Hasil ini sesuai dengan studi sebelumnya bahwa efek antioksidan kombinasi memilliki pengaruh yang lebih baik dibandingkan dengan antioksidan tunggal (32).

Antioksidan yang terkandung dalam kecambah kacang hijau memiliki efek metabolik terhadap jaringan lemak yaitu dengan menurunkan sintesis trigliserida, salah satunya adalah tembaga yang mampu menghambat oksidasi LDL. Selain itu, antioksidan yang terdapat pada kecambah kacang hijau mampu menurunkan kadar kolesterol total yang dipengaruhi oleh diet tinggi kolesterol. Selain itu, kandungan vitamin $\mathrm{C}$ juga turut berperan dalam mempercepat metabolisme beta oksidasi oleh adanya stimulasi sintesis pada jalur karnitin sehingga dapat menurunkan konsentrasi trigliserida dalam darah (33).

Kecambah kacang hijau juga memiliki kandungan vitamin $\mathrm{E}$ yang berperan untuk menghentikan reaksi berantai pada peroksidasi lipid yang terjadi, yaitu dengan memberikan elektron tunggal pada dua reaksi berurutan untuk membentuk senyawa teroksidasi yang stabil. Sementara vitamin $\mathrm{C}$ berperan untuk menekan radikal bebas yang akan menyerang lipid. Vitamin $\mathrm{C}$ sebagai scavenger radikal bebas dapat secara langsung bereaksi dengan superoksida maupun anion hidroksil dan berbagai hidroperoksida lipid. Vitamin C bekerja sama dengan vitamin E untuk menghambat reaksi oksidasi, yaitu dengan mengikat vitamin E radikal yang terbentuk pada proses pemutusan reaksi radikal bebas oleh vitamin E, menjadi vitamin $\mathrm{E}$ bebas yang berfungsi kembali sebagai antioksidan. Vitamin E merupakan vitamin larut dalam lemak yang berfungsi untuk memutuskan reaksi radikal bebas pada jaringan serta merupakan antioksidan yang dominan dalam partikel LDL (34). Selain itu, vitamin C yang berperan sebagai antioksidan sekunder juga memiliki fungsi untuk mempertahankan glutation tereduksi sebagai antioksidan yang penting. Kemampuan vitamin $\mathrm{C}$ tersebut memungkinkan terjadinya hubungan yang sinergis dengan antioksidan lain (antioxidant network) sehingga dapat mempertahankan dan meningkatkan kemampuan sebagai antioksidan (35-37).

Selain itu, beberapa penelitian in vitro yang relevan dengan penelitian ini menyebutkan bahwa antioksidan seperti vitamin E merupakan anti-inflamasi dan sangat berpengaruh untuk menurunkan kadar kolesterol serta mencegah terjadinya obesitas sentral dan penyakit kardiovaskuler, meskipun pada penelitian ini tidak menggunakan parameter sel lemak retroperitoneal $(23,38)$. Kandungan serat yang terkandung dalam kecambah kacang hijau juga berperan untuk menghambat penyerapan lipid di dalam pencernaan. Serat makanan tersebut akan berikatan dengan asam empedu (produk akhir kolesterol) dan keluar bersama tinja. Lebih lanjut, flavonoid yang terdapat pada kecambah kacang hijau merupakan zat yang memiliki potensi bagi kesehatan serta dapat meningkatkan aktivitas lipoprotein lipase sehingga berpengaruh terhadap kadar trigliserida serum (39).

\section{SIMPULAN DAN SARAN}

Pemberian kecambah kacang hijau tidak berpengaruh signifikan dalam menurunkan berat lemak dan jumlah sel, tetapi berpengaruh signifikan pada diameter sel lemak retroperitoneal tikus selama 4 minggu penelitian. Dengan demikian, perlu dilakukan penelitian lebih lanjut terkait pengaruh pemberian kecambah kacang hijau terhadap berat lemak, jumlah sel, dan diameter sel lemak retroperitoneal tikus Sprague Dawley dengan waktu penelitian yang lebih lama dan umur tikus yang lebih dewasa agar parameter lemak yang diteliti benarbenar diketahui dengan baik. 


\section{Pernyataan konflik kepentingan}

Penulis menyatakan tidak ada konflik kepentingan dengan pihak-pihak yang terkait dalam penelitian ini.

\section{RUJUKAN}

1. WHO. Obesity: preventing and managing the global epidemic. Geneva: WHO; 2008.

2. Azwar A. Kecenderungan masalah gizi dan tantangan di masa datang. [series online] 2004 [cited Agustus 2014]. Available from: URL: http://www.academia. edu/28601844/kecenderungan_masalah_gizi_dan_ tantangan_di_masa_datang

3. Bose K, Bhadra M, Mukhopadhyay A. Causes and consequences of obesity. Anthropologist Special [series online] 2007 [cited September 2014];3:223-40. Available from: URL: https://pdfs.semanticscholar.org/c593/74afe2 e06fd593b0483e09e7e69a6136bdfc.pdf

4. Wijga AH, Scholtens S, Bemelmans WJ, Gerritsen J, Brunekreef B, Smit HA, et al. Comorbidities of obesity in school children: a cross sectional study in the PIAMA birth cohort. BMC Pub Health 2010;10(1):184. doi: 10.1186/1471-2458-10-184

5. Riskesdas. Kecenderungan prevalensi obesitas populasi di Indonesia. Jakarta: Riskesdas; 2013.

6. WHO. Cardiovascular disease (CVDs). [series online] 2017 [cited Jan 2018]. Available from: URL: https://www. who.int/news-room/fact-sheets/detail/cardiovasculardiseases-(cvds)

7. Kavanagh K, Jones KL, Sawyer J, Kelley K, Carr JJ, Wagner JD, Rudel LL. Trans fat diet induces abdominal obesity and changes in insulin sensitivity in monkeys. Obesity (Silver Spring) 2007 Jul;15(7):1675-84. doi: 10.1038/oby.2007.200

8. Barzilai N, Gupta G. Revisiting the role of fat mass in the life extension induced by caloric restriction. J Gerontol A Biol Sci Med Sci 1999 Mar;54(3):B89-96. doi: 10.1093/ gerona/54.3.b89

9. Astawan M. Kacang hijau, antioksidan yang membantu kesuburan pria. [series online] 2005 [cited September 2014]. Available from: URL: http://web.ipb.ac.id/ tpg/de/ pubde_ntrtnhlth_kacanghijau.php

10. Shetty K, Lin YT, McCue P, Labbe RG, Randhir R, Ho CY. Low microbial load sprouts with enhanced antioxidants for astronaut diet. SAE Technical Paper 2003-01-2380, 2003. doi: 10.4271/2003-01-2380

11. Winarsi H. Antioksidan alami \& radikal bebas. Yogyakarta: Kanisius; 2007.

12. Purwandhono A. Pengaruh pemberian ekstrak tauge (Vigna radiata (L)) terhadap kadar kolesterol LDL dan perkembangan aterosklerosis pada tikus wistar jantan hiperkolesterolemi [Skripsi]. Jember: Skripsi Universitas Jember; 2013.

13. Tita SA. Efek nefroprotektif ekstrak tauge (Vigna radiata (L.) terhadap peningkatan kadar kreatinin serum tikus wistar yang diinduksi parasetamol dosis toksik [Skripsi]. Jember: Skripsi Universitas Jember; 2013.

14. Iqbal AM. Pengaruh ekstrak tauge (Phaseolus Radiatus) terhadap kerusakan sel ginjal mencit (Mus Musculus) yang diinduksi parasetamol [Skripsi]. Solo: Skripsi Universitas Sebelas Maret; 2010.

15. Kumar V, Abbas AK, Fausto N, Mitchell R. Robbins basic pathology $8^{\text {th }}$ edition. Philadelphia: WB Saunders Company; 2010.

16. Kumar A, Sriwastwa VMS, Lata S. Impact of black T supra on haematology of albino rats. Indian J Sci Res 2011;2(4):21-7.

17. Mitruka BM, Rawnsly HM. Clinical, biochemical, and hematological refference values in normal experimental animals and normal humans 2 ed. USA: Year Book Medical Publishers Inc; 1981.

18. Rodgers WL, Rozin P. Novel food preferences in thiaminedeficient rats. J Comp Physiol Psychol 1966;61(1):1-4. doi: $10.1037 / \mathrm{h} 0022864$

19. Jacques M. Neurobiology of feeding and nutrition. California: Academic Press Inc; 2012.

20. Trilling JS, Jaber R. Selections from current literature: the role of free radicals and antioxidants in disease. Fam Pract 1996;13(3):322-6. doi: 10.1093/fampra/13.3.322

21. Bozaykut P, Karademir B, Yazgan B, Sozen E, Siow $\mathrm{RC}$, Ozer NK, et al. Effects of vitamin $\mathrm{E}$ on peroxisome proliferator-activaed receptor $\gamma$ and nuclear factor-erythroid 2-related factor 2 in hypercholesterolemia-induces atherosclerosis. Free Radic Biol Med. 2014 May;70:17481. doi: 10.1016/j.freeradbiomed.2014.02.017

22. Mayes PA. Struktur dan fungsi vitamin larut-lipid. In: Biokimia Harper edisi XXV. Jakarta: EGC; 2003.

23. Eitenmiller R, Lee J. Vitamin E food chemistry, composition, and analysis. New York: Marcel Decker Inc; 2004.

24. Murray RK, DK Granner, PA Mayes, VW Rodwell. Biokimia Harper. Jakarta: Penerbit Buku Kedokteran EGC; 2003.

25. Habibullah LS, Bilbis MJ, Ladan OP, Ajagbona, Saidu. Agueous extract of hibiscus sabdariffa calyces reduces serum trygliserida. Asian Journal of Biochemistry 2007;2(1):42-9. doi: 10.3923/ajb.2007.42.49

26. Casimir CA, David BM. Food lipids: chemistry, nutrition, and biotechnology second edition. New York: Marcel Dekker AG; 2002.

27. Cryer A, RLR Van. New perspectives in adipose tissue structure, function and development. United Kingdom: Butterworth \& Co; 2014. 
28. Azain MJ, Dorothy BH, Mattew BS, William PF, Dennis EJ. Dietary conjugated linoleic acid reduces rat adipose tissue cell size rather than cell number. J Nutr 2000;130(6):1548-54. doi: 10.1093/jn/130.6.1548

29. Hirsch J, Fried SK, Edens NK, Leibel RL. The fat cell. Med Clin North Am 1989;73(1):83-96. doi: 10.1016/ s0025-7125(16)30693-9

30. Spalding KL, Arner E, Westermark PO, Bernard S, Buchholz BA, Arner P, et al. Dynamics of fat cell turnover in humans. Nature 2008 Jun;453(7196):783-7. doi: 10.1038 /nature06902

31. Michaud DS, Giovannucci EL, Ascherio A, Rimm EB, Forman MR, Willett WC, et al. Asociation of plasma carotenoid concentrations and dietary intake of specific carotenoids in samples of two prospective cohort studies using a new carotenoid database. Cancer Epidemiol Biomarkers Prev 1998;7(4):283-90.

32. Crawford RC, Kirk EA, Rosenfeld ME, LeBoeuf RC, Chait A. Dietary antioxidants inhibit development of fatty streak lesions in the LDL receptor deficient mouse. Arterioscler
Thromb Vasc Biol 1998;18(9):1506-13. doi: 10.1161/01. atv.18.9.1506

33. Burta O, F Tirlea, OL Burta, SM Qadri. Phytotherapy in cardiovascular diseases: from ethnomedicine to evidence based medicine. J Biol Sci 2008;8(2):242-7.

34. Stiphanuk MH. Biochemical and physiological aspects of human nutrition. New York: Saunders; 2000

35. Dawn BM, Allan DM, Smith CM. Biokimia kedokteran dasar: sebuah pendekatan klinis. Jakarta: EGC; 2000.

36. Worhingham RBG, William SR. Nutrition throughout the life cycle. Washington: Mosby; 1996.

37. Steinberg MF, ChaltA. Antioxidant vitamin supplementation and lipid peroxidation in smokers. Am J Clin Nutr 1998 Aug;68(2):319-27. doi: 10.1093/ajen/68.2.319

38. Corrales MVF, Musher DM, Wells GA, Chirinos JA, Chen L, Fine MJ. Cardiac complications in patients with communityacquired pneumonia incidence, risk factors, and association with short-term mortality. Circulation 2012;125(6):773-81. doi: 10.1161/CIRCULATIONAHA.111.040766

39. Lamson DW, Brignall MS. Antioxidants and cancer III: quercetin. Altern Med Rev 2000;5(3):196-208. 